論文・Paper

\title{
$\mathrm{TiO}_{2}$ の水熱結晶化に及ぼすフッ化物 及び脱水の効果について
}

\author{
太田敏孝・山井跾*・斎藤: 肇 \\ ( 名古屋大学 工学部 応用化学科 $)$
}

通常の水熱反応に脱水反応を併用することにより, 無定形酸化チタンからの $\mathrm{TiO}_{2}$ の結晶化をつ

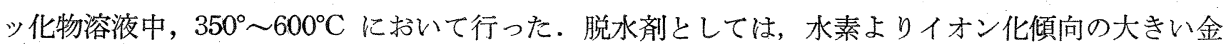
属を用いた。

$\mathrm{KF}$ 溶液では主にチタン酸カリが，そして CsF 溶液ではアナターゼが生成した。一方， $\mathrm{NaF}$ 溶 液では， $420^{\circ} \mathrm{C}$ 以上で，ルチル結晶が溶解析出過程により生成した。 そして，Zn を用いて脱水を 行った場合には，通常の水熱法と比較して大きな結晶が生成した. この場合の $\mathrm{Zn}$ の酸化反応を検 討した結果, 短時間にて終了していたことが分り, 脱水の効果は結晶化の初期, 恐らく核生成時に 働いたことが考えられた.

更に，結晶成長を行うため，種々の金属を用いて脱水を長時間続けることを試みたが，良好な結 果は得られなかった。また，初めにルチル粉末を核として加えて反応を行った場合，脱水により幾 分か成長することが観察された.

(1979 年 11 月 5 日受付)

\section{Effects of Fluoride and Dehydration on the Hydrothermal Crystallization of $\mathrm{TiO}_{2}$}

\author{
Toshitaka OOTA, Iwao YAMAI* and Hajime SAITO \\ ( Department of Applied Chemistry, Faculty of Engineering, Nagoya University, Nagoya-shi 464) \\ * Ceramic Engineering Laboratory, Nagoya Institute of Technology, Tajimi-shi 507
}

To investigate the effects of dehydration on ordinary hydrothermal reactions, $\mathrm{TiO}_{2}$ was crystallized hydrothermally from amorphous titanium dioxide. The so-called hydrothermal dehydration method was a new one, that is, it was the flux evaporation method under hydrothermal conditions. In this method the supersaturation required to undergo crystal growth might be achieved by the dehydration of a part of water in an autoclave. Various kinds of metal with higher ionization tendencies than that of hydrogen can be used as dehydration agents.

Hydrothermal reactions were carried out at $350^{\circ} \sim 600^{\circ} \mathrm{C}$ in fluoride solutions such as $\mathrm{KF}$, $\mathrm{CsF}$ and $\mathrm{NaF}$. At lower temperatures, amorphous titanium dioxide gels were converted into anatase. At higher temperatures, rutile was formed through a solution and precipitation process from gels or anatase, which was thermodynamically unstable with respect to rutile. In $\mathrm{KF}$ solutions, fibrous $\mathrm{K}_{2} \mathrm{Ti}_{6} \mathrm{O}_{13}$ was formed as a by-product. In $\mathrm{CsF}$ solutions, metastable anatase existed at temperatures up to $600^{\circ} \mathrm{C}$. Consequently, $\mathrm{KF}$ and $\mathrm{CsF}$ appeared to be unsuitable solvents for crystallization of rutile. On the other hand, in $\mathrm{NaF}$ solutions, the anatase-rutile transformation was rapidly accelerated at $420^{\circ} \mathrm{C}$ or above, and blue well-developed rutile crystals precipitated.

The crystals obtained by the hydrothermal dehydration method with $\mathrm{Zn}$ metal were larger in comparison with the ordinary hydrothermal method. The weight gains of $\mathrm{Zn}$ to $\mathrm{ZnO}$ and the increase in the $\mathrm{H}_{2}$ pressure evolved by the dehydration process suggested that the oxidation of $\mathrm{Zn}$ metal was almost completed in a short time. This dehydration, therefore, would give an adequate supersaturation in the solution at the initial stage in crystallization, so that nuclei of the rutile would be formed. It was assumed that the nuclei grew to be 
large crystals by ordinary hydrothermal reactions subsequently. If the dehydration might be continued until a later stage, much larger crystals should be grown. According to the assumption that dehydration was controlled by the reactivity of a metal, $\mathrm{Al}, \mathrm{Fe}, \mathrm{Mg}$ and $\mathrm{Pb}$ were used as dehydration agents; no positive results were obtained, however. When a small amount of rutile-type $\mathrm{TiO}_{2}$ powder was added as nuclei, crystal growth was slightly observed to proceed by dehydration.

[Received November 5, 1979]

Key-words : Hydrothermal, Crystallization, Dehydration method, $\mathrm{TiO}_{2}$, Rutile, Amorphous titanium dioxide, Fluoride solutions

\section{1. 緒 言}

水熱法は高温高圧下に結晶を合成及び育成する方法で あるが，原理的には水溶液からの生成と類似している. 溶液からの結晶の析出には過飽和状態が必要とされ, 通 常これは温度降下により得られている. しかし, 溶解度 の温度係数の小さいものでは温度を大きく変えなければ ならないし，溶解度の小さいものでは大量の飽和溶液を 用いないと大きな結晶はつくれない，過飽和を得る別の 方法としては蒸発法があり, 古くから簡便な方法として 行われ，溶解度の小さいものなどに適用されている. 水 熱脱水法とは，この蒸発法を水熱下にも適用し，通常の 水熱法より低温低圧で溶解度及び溶解度の温度係数の小 さいものに対しても結晶成長を行わせる方法である.

水熱下に溶液を蒸発させる方法としては, 反応容器中 に水素よりイオン化傾向の大きい金属を入れ，これと氷 蒸気との反応により, 水の一部を金属酸化物と水素の形 で脱水することを考えた，そして，既に著者らは，この

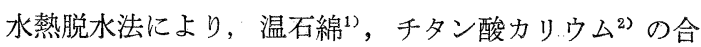
成を行い，良好な繊維状晶が得られることを報告した。 本報では，これらの結晶成長に対する脱水の効果を更に 詳しく検討するため，チタン酸カリウムの原料に用いた 水酸化チタンから $\mathrm{TiO}_{2}$ への水熱結晶化を脱水法の適用 例として選び，実験を行った結果を報告する。

この $\mathrm{TiO}_{2}$ には 3 種の変態, アナターゼ, ブルッカイ ト, ルチルが存在するが, 安定相はルチルのみである. 通常の水熱下においては，アナタ一ゼ，ルチルの 2 相が 存在し，ルチルへの転移に関して多くの報告がある ${ }^{3) ~ 6) . ~}$ そこでは, 無定形 $\mathrm{TiO}_{2}$ あるいはアナターゼからのルチ ルの生成に対して, 温度, 圧力の增加 ${ }^{3,4)}$ 及びフッ化物 などの鉣化剂の存在 ${ }^{5)}$ が触媒作用をすることが知られて いる、また，Matthews は，アナターゼは無定形 $\mathrm{TiO}_{2}$ から構造の再配列により容易に生成し, ルチルは溶解析 出により結晶化することを報告している6).したがって， 本実験では，フッ化物溶液からのルチル析出に対して主 な検討を行うことにした。 これまで，ルチル単結晶の水 熱育成は温度こう配法によるものが主で, そこではかな りの高温高圧が必要とされた ${ }^{73,8)}$ 。これに対し, 脱水法 では，上り稳やかな条件下汇新いてルチルの析出を促進 できると考えられる。

\section{2. 実 験}

\section{1 原料}

水酸化チタンは，アナターゼ型 $\mathrm{TiO}_{2}$ の製法 ${ }^{9}$ を参考 にして, 硫酸を触媒とした市販試薬特級四塩化チタンの 加水分解により調製した. この際生成した $\mathrm{HCl}$ を, 多 量の蒸留水によりよく洗浄し, 硝酸銀にて $\mathrm{Cl}^{-}$イオン の除去を確認したこの物質を $100^{\circ} \mathrm{C}$ において一昼夜 乾燥した後の含水量は, $\mathrm{TiO}_{2} \cdot n \mathrm{H}_{2} \mathrm{O}$ とした場合, $n=$ 1.0〜1.9 であり，X 線粉末回折により無定形であるこ とが確認され，これを粉砕して出発物質とした.

一部の実験では, 市販試薬特級 $\mathrm{TiO}_{2}$ を $1200^{\circ} \mathrm{C}$ にお いて 2 時間焼成して得たルチル型 $\mathrm{TiO}_{2}$ 粉末を, 水酸化 チタンとともに原料として使用した。

溶液は, 市販試薬特級 $\mathrm{KF}, \mathrm{CsF}, \mathrm{NaF}$. に蒸留水を加 え, 所望の濃度の溶液を調製した。

脱水剂には, 市販試薬特級粉末状及び粒状 $\mathrm{Zn}$, 試薬 1 級粉末状及び粒状 $\mathrm{Al}$ ，砂状 $\mathrm{Mg}$ ，砂状 $\mathrm{Pb}$ 金属㐋し て電解鉄粉及び鉄板をそのまま使用した。

\section{2 実験方法}

反応装置は, 内容積約 $140 \mathrm{ml}$ のステンレス又はハス テロイ製自緊式オートクレーブを用い，この中に水酸化 チタンを䀣濁させた溶液を $30 \mathrm{cc}$ 入れた試料容器と, 脱 水剤を入れた容器を図 1 のように装てんし, 電気炉中に て加熱した. 試料容器は, 外径 $20 \mathrm{~mm}$, 長さ $100 \sim 200$

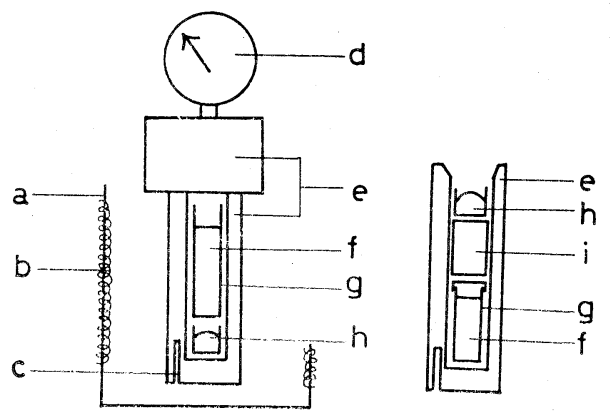

Fig. 1. Apparatus for the hydrothermal dehydration method.

$\mathrm{a}$ : Furnace, b : Heater, c : Thermocouple well, $\mathrm{d}$ : Pressure gauge, e : Autoclave, $f$ : Nutrient, g : Pt-tube, h : Dehydration agent, i : Stainless rod. 
$\mathrm{mm}$, 厚さ $0.05 \mathrm{~mm}$ の白金管を, そして脱水剤の容器 は，長さ $30 \sim 50 \mathrm{~mm}$ の白金管のほか，アルミナ質タン マン管及び銅製容器を使用した。

反応温度は， $350^{\circ} \sim 600^{\circ} \mathrm{C}$ の範囲で行い，昇温時間は $300^{\circ} \mathrm{C}$ まで 1 時間, $500^{\circ} \mathrm{C}$ まで約 2 時間を要し, 冷却は 放冷とし, $500^{\circ} \mathrm{C}$ から $400^{\circ} \mathrm{C}$ まで降下するのに 30 分， $400^{\circ} \mathrm{C}$ から $300^{\circ} \mathrm{C}$ まで 1 1.5 時間を要した.

脱水反応は，金属と水との反応により発生した水素圧 の増加及び反応後の金属の重量増により，その進行を推 定した.

生成物は，水洗い，風乾後， $\mathrm{X}$ 線粉末回折，顕微鏡観 察を行った. 生成したルチルとアナターゼの量比は, ル チルの (110) 反射と, アナターゼの (101) 反射のピーク 面積比から見積もった ${ }^{10)}$. また，比重約 4.1 の Clerici 溶液を調製し，ルチル結晶の確認を行った。

\section{3. 結果及び考察}

\section{1 反応条件の検討}

溶液として $\mathrm{TiO}_{2}$ の水熱合成に適していることが知ら れている各種フッ化物溶液を用いて，反応条件について 検討を行った.この際, チタン酸カリウムの合成におい て効果のあった Zn を用いて, 脱水法の適用の可否につ いても併せて検討した. Kuznetsov ${ }^{7)}$, Passaret ら ${ }^{87}$ は, ルチル単結晶の水熱合成を温度 $500^{\circ} \sim 600^{\circ} \mathrm{C}$, 充てん率 $0.6 \sim 0.7$, 圧力 $\sim 1000$ 気圧の条件下で行っているが, 本実験においては装置及び脱水法の都合上，より温和な 条件下に拉いて行った. すなわち, 温度こう配法では, 成長, 溶解ゾーンの対流のため, 高充てん率にて液相を 必要とするが，脱水法では低充てん率の方が脱水が効果 的に㗢くこと党 行った。これは, ほほ臨界充てん率に等しく, 臨界温度 まで液相が存在していると考えられる。しかし，ルチル の結晶化にはより高温にする必要があり, 本実験の水熱 状態について詳しくは分らなかった。実際には, 生成物 はすべて試料用白金管内底部に存在し，対流などによる 管外一の移動はなく，更に脱水剤の混入む検出されなか った。したがって，本実験における反応は，所定温度に おいて， ある程度の $\mathrm{TiO}_{2}$ が管内液相中に溶解し析出す る等温下に扔ける粒成長であると考えられた，なお，特 に断らない限り，脱水剤はオートクレーブ底部に設置 し，脱水を行わない場合も，温度分布及び温度こう配な どを同一条件にするため, 脱水剤容器のみあるいはステ ンレス棒を同様に装てんした.

\section{$3.1 .1 \mathrm{KF}$ 溶夜における反応}

従来 $\mathrm{TiO}_{2}$ 結晶は，主に $\mathrm{KF}$ 溶液を用いて水熱合成 が行われ7,8),11), その理由として $\mathrm{TiO}_{2}$ の溶解度が高 く, 他のフッ化物と比較して最む大きな自然核生成結晶 が得られることなどが考えられている。したがって，本
Table 1. Experimental conditions and results in $\mathrm{KF}$ and $\mathrm{CsF}$ solutions.

\begin{tabular}{|c|c|c|c|c|c|c|}
\hline Iro. & Solvent & $\begin{array}{l}\text { Conc. } \\
(\mathrm{mol} / \mathrm{kg})\end{array}$ & $\begin{array}{l}\text { Temp. } \\
\left({ }^{\circ} \mathrm{C}\right)\end{array}$ & $\begin{array}{l}\text { Press. } \\
\left(\mathrm{kg} / \mathrm{cm}^{2}\right)\end{array}$ & $\begin{array}{l}\text { Time } \\
\text { (day) }\end{array}$ & Products \\
\hline 1 & $\mathrm{KF}$ & 1.0 & 350 & 103 & 1 & A \\
\hline 2 & $\mathrm{KF}$ & 1.0 & 400 & 160 & 1 & $A \simeq R$ \\
\hline 3 & $\mathrm{KF}$ & 1.0 & 420 & 174 & 2 & $A<R$ \\
\hline $4^{*}$ & $\mathrm{KF}$ & 1.0 & 420 & 249 & 1 & $A>R$ \\
\hline 5 & $K F$ & 2.0 & 420 & 200 & 2 & $A>R, K$ \\
\hline $6^{*}$ & $\mathrm{KF}$ & 2.0 & 420 & 255 & 2 & $A>R, K$ \\
\hline 7 & $\mathrm{KF}$ & 1.0 & 450 & 275 & 2 & $A>R, K$ \\
\hline $8^{*}$ & $\mathrm{KF}$ & 1.0 & 450 & 301 & 1 & $A<R(24 \mu)$ \\
\hline 9 & $\mathrm{KF}$ & 1.0 & 475 & 283 & 1 & $A>R$ \\
\hline $10 *$ & $\mathrm{KF}$ & 1.0 & 475 & 356 & 1 & $A<R(36 \mu)$ \\
\hline 11 & $\mathrm{KF}$ & 1.0 & 525 & 339 & 1 & $R, K$ \\
\hline 12 & $\mathrm{Cs} \mathrm{F}$ & 1.2 & 420 & 140 & 1 & A \\
\hline $13 *$ & $\mathrm{CsF}$ & 1.2 & 420 & 200 & 1 & $A \gg R(\operatorname{trace})$ \\
\hline 14 & $\mathrm{CsF}$ & 1.2 & 450 & 258 & 4 & A \\
\hline 15 & Csi & 1.2 & 470 & 277 & 1 & A \\
\hline
\end{tabular}

実験においても初めに KF 溶液を用いて反応を行った。 代表的な結果を表 1 に示す.

適当な $\mathrm{KF}$ 濃度を選定するため, $420^{\circ} \mathrm{C}$ において 2 日 間反応を行った。 $1 \mathrm{~mol} / \mathrm{kg}$ に掠いてはルチルが生成し ていたが， $2 \mathrm{~mol} / \mathrm{kg}$ ではチタン酸カリウム針状晶が副 生し， $4 \mathrm{~mol} / \mathrm{kg}$ ではほとんどチタン酸カリウムに変化 した. Kuznetsov によれば, $2 \mathrm{~mol} / \mathrm{kg}$ 以上ではフッ素 を含むチタン化合物が生成する゙ ことが予想されたが， 本研究では六チタン酸カリウム以外の副生成物は確認さ れなかった。 また $1.5 \mathrm{~mol} / \mathrm{kg}$ 以下の濃度では溶解量が 少ないので，1.5〜2 mol $/ \mathrm{kg}$ が適していると報告されて いる7)が，本研究ではチタン酸カリウムの生成及び脱水 による濃度の増加を考慮し, $1 \mathrm{~mol} / \mathrm{kg}$ 溶液にて反応温度 の検討を行った。

$350^{\circ} \mathrm{C}$ においては, 生成物はアナターゼ単一相で, 光 学顕徽鏡観察から，原料に用いた水酸化チタンがそのま ま残存しているのと同様な状態であると考えられた。ル チルは $400^{\circ} \mathrm{C}$ 以上において生成したが， $450^{\circ} \mathrm{C}$ では 2 日間， $525^{\circ} \mathrm{C}$ では 1 日の反応でチタン酸カリウムが生成 し，ルチルの生成量は減少した。また，アナターゼは反 応時間により異なるが， $475^{\circ} \mathrm{C}$ では 1 日の反応後におい

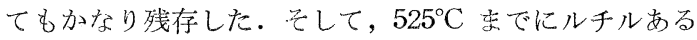
いはチタン酸カリウムに変化した.

以上の結果から, Matthews の報告6) と同様に, アナ ターゼは原料がそのまま変化し、ルチル及びチタン酸カ リは溶解種からの析出であると推定できる。したがって 溶存 $\mathrm{TiO}_{2}$ が溶液から析出する時にカリウムと反応して チタン酸カリウムが生成した場合は，原料として残存し 


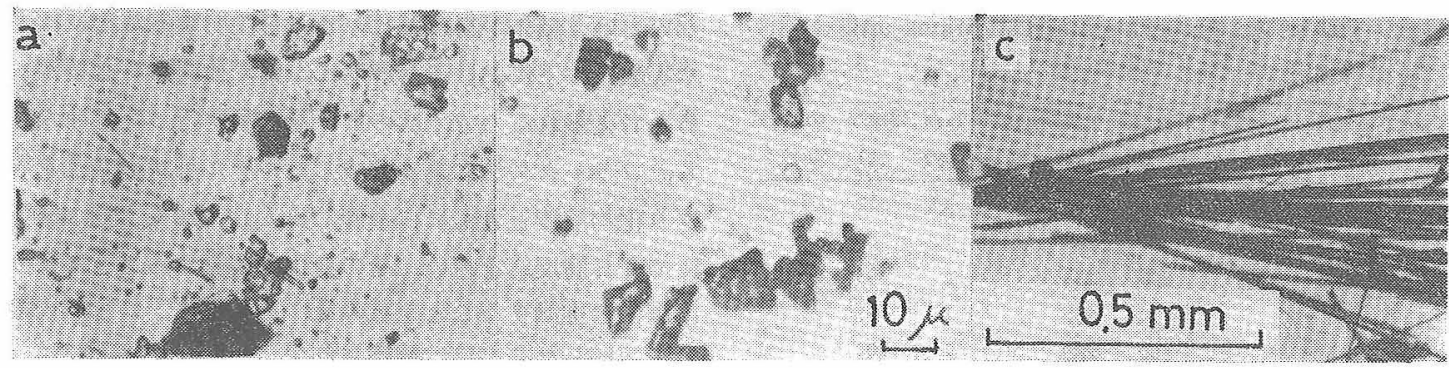

Fig. 2. Photographs of the crystals obtained from KF solutions.

a : $\mathrm{A}>\mathrm{R}$, by the ordinary hydrothermal method in $1 \mathrm{~mol} / \mathrm{kg} \mathrm{KF}$ at $475^{\circ} \mathrm{C}$ (No. 9).

b : A $<R$, by the hydrothermal dehydration method in $1 \mathrm{~mol} / \mathrm{kg} \mathrm{KF}$ at $475^{\circ} \mathrm{C}$ (No. 10 ).

c : $\mathrm{K}_{2} \mathrm{Ti}_{6} \mathrm{O}_{13}$ needles, by the hydrothermal dehydration method in $2 \mathrm{~mol} / \mathrm{kg} \mathrm{KF}$ at $420^{\circ} \mathrm{C}$ (No. 6).

ているアナターゼに対し，相効的にルチルの生成量が減 少したと考えられる。

先た，図 2 に示すように，脱水を行わなかった場合と 比較して，Znにより脱水を行った場合， $1 \mathrm{~mol} / \mathrm{kg}$ では $475^{\circ} \mathrm{C}$ に秃いて大きなルチル結晶が，そして $2 \mathrm{~mol} / \mathrm{kg}$ では $420^{\circ} \mathrm{C}$ に秝いて特に長くて太い約 $5 \mathrm{~mm}$ のチタン 酸力リウム針状晶が析出した。したがって，脱水は結晶 の䉼出を促進することが考えられる。しかし，KF 溶液 の場合，脱水はチタン酸カリウムの析出に対しても同様 に教果を及ぼすため， $\mathrm{TiO}_{2}$ の析出のみに齐する検討に は，チタニアとの反応性の低い溶液を用いる必要がある と考えられる。

\section{$3.1 .2 \mathrm{CsF}$ 溶液における反応}

$\mathrm{CsF}$ 溶液の場合， $\mathrm{KF}$ より低温に晾いてルチル単結晶 莫成できることが報告8) されているが，本类験では， 表 1 に示すように， $470^{\circ} \mathrm{C}$ までの反応に拉いてルチル は全く析出せず，アナターゼ相のみであり，これは顕微 鏡観察の結果，原料とほとんど変わっていない粉末でめ

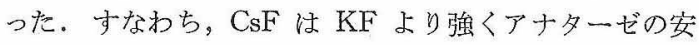
定化に働き，ルチルの析出には更に高温に招訬る反応が 必要であると考えられた. そこで, 温度をオートクレー ブ下部 $600^{\circ} \mathrm{C}$, 上部 $500^{\circ} \mathrm{C}$ とし，充てん率 0.6 ，圧力 $750 \mathrm{~kg} / \mathrm{cm}^{2}$, 反応時間 3 日の条件下で, 白金管に封入し て反灾を行った。その結果，啫青色の最大 $0.5 \mathrm{~mm} の$



Fig. 3. Photographs of the crystals obtained from $\mathrm{CsF}_{S}$ solutions.

a : Anatase powder.

$\mathrm{b}$ : Rutile crystals precipitated on inner wall of Pt-tube by the hydrothermal dehydration method.
ルチル単結晶が数十個自然核生成したが，なだ主生成相 はアナターゼ粉末であった。

Zn により脱水を行った場合は，図3に示すように， $420^{\circ} \mathrm{C}$ にて白金管内壁に少量のルチル微結晶が析出して いるのが観察された。これは，わず的溶解していた $\mathrm{TiO}_{2}$ が脱水により過飽和となり析出したためであると 考えられる。また同定はできなかったが，恐らく報告8 にある $\mathrm{CsF}$ ¿ $\mathrm{TiO}_{2}$ の化合物と考えられる副生成物が 微量検出された。

以上の結果から，脱水によるルチルの析出が認められ たが，CsFによるアナターゼの安定化及び副生成物の析 出などのため， $\mathrm{CsF}$ 溶液に捻ける脱水法の検討は複雑に なると考えられ，次に NaF について実験を行った。

\subsection{3 $\mathrm{NaF}$ 溶液における反応}

$\mathrm{NaF}$ 溶液中では，Kuznetsov?? 及び Passaret ら ${ }^{82}$ の 結果ふら推定して，400 ほどの低温においては $\mathrm{TiO}_{2}$ の溶解度はかなり小さく，ルチルの析出は困難であるら と予想されたが，結果俵 2 に示すように， $\mathrm{KF}, \mathrm{CsF}$ 雨 溶液と比較して, より低温においてもルチルが生成し, $420^{\circ} \mathrm{C}$ 以上で青く着色した数 $\mu \mathrm{m}$ 数十 $\mu \mathrm{m}$ のルチル 結晶が主生成相として析出した。な就， $\mathrm{NaF}$ は水への 溶解度が小さいため，反応は主に $0.7 \mathrm{~mol} / \mathrm{kg}$ にて行っ た。充た $\mathrm{KF}, \mathrm{CsF}$ 溶液における反応と異なり，副生成 物は全く䘳出されず，直接試料容器中に $\mathrm{NaF}$ 粉末を入 れ高濃度の $\mathrm{NaF}$ 溶液として反応を行った 場合に拈いても，全く $\mathrm{Na} の$ 化合物は生成 しなかった。

Znにより脱水を行った場含には，特 に $420^{\circ} \mathrm{C}$ に掠いて通常の水熱法に比べ, 大 き結晶が析出した。したがって，NaF 浴 液においては低温でルチルが生成し，脱水 の効果すあり，更に $\mathrm{TiO}_{2}$ との反応性す小 さいと考觉られ，単純にルチルの析出に及 ぼす脱水の效果を検討するのに適している と漖えられたので，以下 $\mathrm{NaF}$ 溶液にて反 応を行った。 
Table 2. Experimental conditions and results in $\mathrm{NaF}$ solutions.

\begin{tabular}{lllllll}
\hline No. Dehydration & $\begin{array}{l}\text { Temp. } \\
(\mathrm{g})\end{array}$ & $\begin{array}{l}\text { Press. }\left(\mathrm{P}_{\mathrm{H}_{2}}\right) \\
\left(\mathrm{kg} / \mathrm{cm}^{2}\right)\end{array}$ & $\begin{array}{c}\text { Time } \\
(\text { day })\end{array}$ & $\begin{array}{c}\text { Yield } \\
(\%)\end{array}$ & $\begin{array}{c}\text { Size } \\
(\mu \mathrm{m})\end{array}$ \\
\hline 1 & - & 350 & 135 & 1 & 12 & 8 \\
2 & - & 420 & 228 & 1 & 85 & - \\
3 & - & 420 & 233 & 2 & 93 & 20 \\
4 & - & 450 & 253 & 1 & 97 & 24 \\
5 & - & 500 & 299 & 1 & 100 & 20 \\
6 & - & 550 & 400 & 1 & 97 & 12 \\
7 & Zn powder 10 & 420 & $187-10$ & 1 & 99 & 32 \\
8 & Zn powder 10 & 420 & $222-8$ & 3 & 78 & 60 \\
9 & Zn powder 10 & 500 & $255-5$ & 1 & 98 & 20 \\
10 & Zn granules 15 & 400 & $244-64$ & 1 & 100 & 60 \\
11 & Zn granules 10 & 450 & $337-30$ & 3 & 90 & 20 \\
12 & Al granules 10 & 420 & $412-145$ & 2 & 90 & 32 \\
13 & Fe powder 10 & 420 & $332-48$ & 1 & 56 & - \\
14 & Mg powder 5 & 420 & $335-55$ & 1 & 62 & - \\
\hline
\end{tabular}

また，水熱法及び水熱脱水法の両方とも， $420^{\circ} \mathrm{C}$ 付近 において大きな結晶が生成し, 高温では微結晶となる傾 向が認められたが，この理由の一つとして， $\mathrm{NaF}$ 溶液 ではアナターゼからルチルへの溶解析出による転移が $420^{\circ} \mathrm{C}$ 付近において顕著になり, この温度ではルチルの 成長とアナターゼの溶解による原料の供給とが適当に一 致したためであることが考えられる。その証拠として， 原料に初めからルチル粉末のみを用いた場合にはほとん ど成長は観察されず微結晶のまま存在した.すなわち， 安定なルチルからは溶解析出が困難で, 結晶成長が非常 に遅いため大きな結晶が生成しにくくなると考えられ る. したがって, 高温における反応では非常に速くルチ ルが生成されるため, 同様な結果として, これらいった ん生成したルチル微結晶からは大きな結晶へ成長しなか ったと考えられる.

\section{1 .4 溶液中のアルカリイオンの作用について}

$\mathrm{TiO}_{2}$ の溶解に対してフッ化物が適していることは数 多く報告され(5),7),8),12),13)，その場合，フッ素は $\mathrm{Ti}^{4+}$ と の錯体を形成しやすく $\mathrm{TiO}_{2}$ の結合を切断することが考 えられているが，一方陽イオンについてはほとんど説明 されていない。フッ化物溶液中への $\mathrm{TiO}_{2}$ の溶解に関し ては, Kuznetsovにより, $470^{\circ} \sim 600^{\circ} \mathrm{C}$ の温度範团では， 高温側から低温側へ輸送される $\mathrm{TiO}_{2}$ の量は, $\mathrm{KF}>\mathrm{NaF}$ であること7)，そして Passaret により， $\mathrm{KF}$ 及び $\mathrm{CsF}$ 溶液中への $\mathrm{TiO}_{2}$ の溶解度が測定され， $400^{\circ} \mathrm{C}$ 付近では 極めて小さく, $500^{\circ} \sim 600^{\circ} \mathrm{C}$ 以上に扔いて初めて急速に 増加すること采などが報告されている。

本実験においては， $\mathrm{NaF}$ 溶液にて反応を行った場合 に溶解析出により大きなルチル結晶が生成し, 一方 $\mathrm{KF}$, $\mathrm{CsF}$ 溶液では水酸化チタンの脱水により生成したと考え られる粉末状の溶解析出過程を経ていないアナタ一ゼが 主生成物であり， NaF 溶液に比べほとんど溶解してい
ないという結果が得られた。これを説明するためには， 本実験条件下における溶解度について検討する必要があ ると考えられるので, 次のような実験を行った. すなわ ち，フラックス法により合成したルチル針状単結晶を各 フッ化物溶液とともに白金管に封入し, $420^{\circ} \mathrm{C}$ 及び $450^{\circ} \mathrm{C}$ にて 4 日間反応を行い，その変化を観察することにより 溶解性を推測することを試みた。 その結果，いずれの場 合も溶解したこん跡は観察されず，この温度範囲ではフ ッ化物溶液中へのルチルの溶解度は非常に小さいことが 分った. したがって, $\mathrm{NaF}$ が $\mathrm{TiO}_{2}$ の溶解に適してい たという本実験結果は, 溶解度よりむしろ溶解速度ない し溶解析出の速度の差といら観点から考察される必要が あると考えられた。

本実験においては，原料に水酸化チタンを用いてお り， $\mathrm{TiO}_{2}$ の結晶化に関しては，この水酸化チタン及び 脱水され生成したアナターゼがルチルに比べ不安定でよ り溶解性に富むため，ルチルに対して過飽和となり，ル チルが析出すると考えられる. そして溶解度が非常に小 さいので, この過程は, ある飽和溶解量のもとで連続的 に進行していくと考えられ，この過程が速いほど結晶化 が速いと推定される. フッ化物溶液中の $\mathrm{TiO}_{2}$ の溶解種 としては泉らにより報告されているような $\mathrm{TiOF}_{3}{ }^{-1}$ など のオキシフルオロ錯体あるいはこれらの複合イオンが重 合したもの ${ }^{11)}$ 侤えられるが，これらの安定性は溶液中 のアルカリイオンとの相互作用により異なり ${ }^{14)}$, その結 果, 各々のアルカリ溶液中に抒ける結晶化速度に差が生 ずると推定される.ここで, $\mathrm{K}^{+}, \mathrm{Cs}^{+}$は $\mathrm{Na}^{+}$に比べ $\mathrm{TiO}_{2}$ の溶解種との相互作用が強いと仮定すると, $\mathrm{K}^{+}$, $\mathrm{Cs}^{+}$溶液中では $\mathrm{Na}^{+}$溶液中に比べ溶解種がより安定と なり， $\mathrm{TiO}_{2}$ の析出速度はより遅くなると考えられる。 したがって,これらの溶液ではアナターゼが大量に残存 し, 一方 $\mathrm{Na}^{+}$溶液中では容易に溶解析出が進むためル チル結晶が成長したと説明できる. また十分に高温の場 合には, 反応速度は速く, しかも溶解度も大きいので, いずれの溶液においてもルチルの析出が観察されたと考 えられる.なお，この相互作用が安定な化合物を形成す るほど強い場合は，チタン酸カリウムのような化合物の 析出定生ずると考えられる.

また，溶解種ではなく， $\mathrm{TiO}_{2}$ 表面上にフッ化アルカ リが吸着して形成された表面状態が，KF 及び CsF 溶 液に招いては低温でも安定なため，更に溶解されること が妨げられ，溶解速度が極めて遅くなり，ての結果，ア ナターゼが安定化されルチルが析出しなかったとも考え られる.これについては大きなイオンの拡散が遅いこと に一つの原因がある ${ }^{14)}$ と考えられる。

\section{2 脱水法の検討}

\subsubsection{Zn による脱水反応について}

$\mathrm{Zn}$ 粉末により脱水反応を行った場合, いすれの溶液 
に捄いても通常の水熱法のみの場合と比較して大きな結 晶が析出する傾向にあり，特に $\mathrm{NaF}$ では $420^{\circ} \mathrm{C}$ に忬 いて大きなルチル結晶が生成したので，この場合の $\mathrm{Zn}$ の脱水反応について検討した。

1 日反応した後に $\mathrm{Zn}$ 粉末はすべて $\mathrm{ZnO}$ 、酸化され，


Fig. 4. (a) The time-dependence of the percentage of $\mathrm{ZnO}$ (2) and the residual pressure of $\mathrm{H}_{2}$ (O) produced by dehydration with $\mathrm{Zn}$ granules $(15 \mathrm{~g})$ at $420^{\circ} \mathrm{C}, 20 \%$ fill of $0.7 \mathrm{~mol} / \mathrm{kg} \mathrm{NaF}$ solutions. (b) The temperature-dependence for $0 \mathrm{~h}$ () and for 1 day $(\diamond)$, in which the time taken to reach at a desired temperature was from 1.5 to $2 \mathrm{~h}$.
乳白色粉末として脱水剤容器中に存在していた。したが って，Znの酸化は 1 日以内に終了していたことが推測 され，脱水反心の成間経過を粒状覀鉛 $15 \mathrm{~g}$ を用いて, その重量増, 水素残圧から推定した。ここで，急冷は行 っていないため，各温度に执いて0 時閒の反応，才なわ ち所定温度に達した時点で泠却した実験を行い，昇温及 び椧却中の反応とした，結果は図 4 に示すように，Zn の酸化は $350^{\circ} \sim 400^{\circ} \mathrm{C}$ に㧍いて開始され，500 ${ }^{\circ} \mathrm{C}$ では極 內て短時閒内に終了し， $420^{\circ} \mathrm{C}$ に扮いては 5 時間以内に

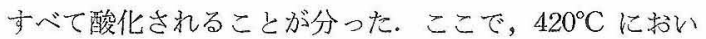
ては昇温時間中の脱水注無視してよいと考えられるが， $500^{\circ} \mathrm{C}$ に打いては昇温中に Zn は酸化された可能性が大 きく，をの結果として，脱水を行わなかった場合の結果 と同様な生成物が析出したことが考えられる。

以上の結果加ら， $420^{\circ} \mathrm{C}$ 亿挍ける $\mathrm{Zn}$ による脱水反応 はルチル結晶の析出の初期に拉いて㗢き, その後は通常 の水熱成長が続いたと考光られる.したがって，ルチル の成長に対して長時閒の脱水孛続けるため, 脱水郕部分 の温度及び Zn の形状あるい他他の金属の使用などを検 部守る必要が交る。

\section{2 .2 脱水剂の検討}

適当な脱水剂走得るため， $\mathrm{Zn}$ の外に， $\mathrm{Al}, \mathrm{Fe}, \mathrm{Mg}$ ， $\mathrm{Pb}$ 金属を朋いて $\mathrm{TiO}_{2}$ の水熱結晶化を行った．代表的 な結果学 2 及び図 5 亿示す，金属の充てん量は $\mathrm{Zn} の$ 場合を参考に $1 / 3 \sim 1 / 10 \mathrm{~mol}$ 用い，反応後の生成酸化物 及び発生水素生加ら脱水反応㐳ついて考察し，析出ルチ ル結晶との関係を検討した。

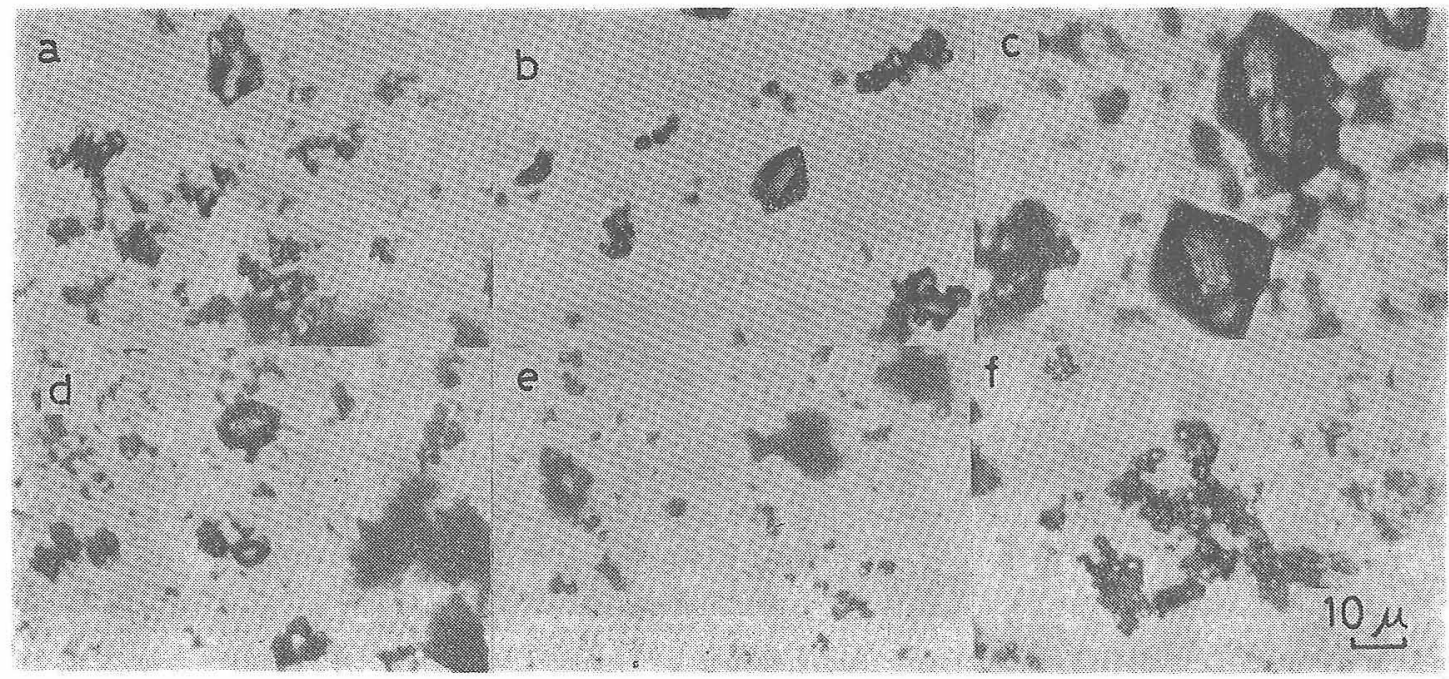

Fig. 5. Photographs of the crystals obtained from $\mathrm{NaF}$ solutions at $420^{\circ} \mathrm{C}$.

a : For 2 days by the ordinary hydrothermal method (No. 3)

b : For 1 day by the hydrothermal dehydration method with $\mathrm{Zn}$ (No. 7).

c : For 3 days with $\mathrm{Zn}$ (No. 8).

d : For 2 days with Al (No. 12).

e : For 1 day with $\mathrm{Fe}$ (No. 13).

f : For 1 day with $\mathrm{Mg}$ (No. 14). 
$\mathrm{Al}$ は $\alpha-\mathrm{Al}_{2} \mathrm{O}_{3}$ 及び水酸化アルミニウムに変わり，こ の反忘は $\mathrm{Zn}$ とほほ同様で， $350^{\circ} \sim 400^{\circ} \mathrm{C}$ に抒いて始ま り，粉末状 Al $10 \mathrm{~g}$ を用いた場合， $420^{\circ} \mathrm{C}$ に招いて 3 時 間ですべてが反応した。䊀状の $\mathrm{Al}$ を用いた場合は， $450^{\circ} \mathrm{C}$ において 4 日閒反応を行った後も，一部金属粒が 残存した。この場合，粒の表面の反応は非常に速く，残 存している $\mathrm{Al}$ は酸化物層に柬まれているため, その後 の反応はかなり遅くなった， $420^{\circ} \mathrm{C}$ においては，10 gの $\mathrm{Al}$ 粒を用いた場合，約 $5 \mathrm{~g}$ が 2 時間で酸化され，脱水 剤としての效果は Zn とほぼ同様であると考えられ，実 際に析出したルチル結晶も，Zn の場合と同様に，比較 的大きな結晶が観煞された。
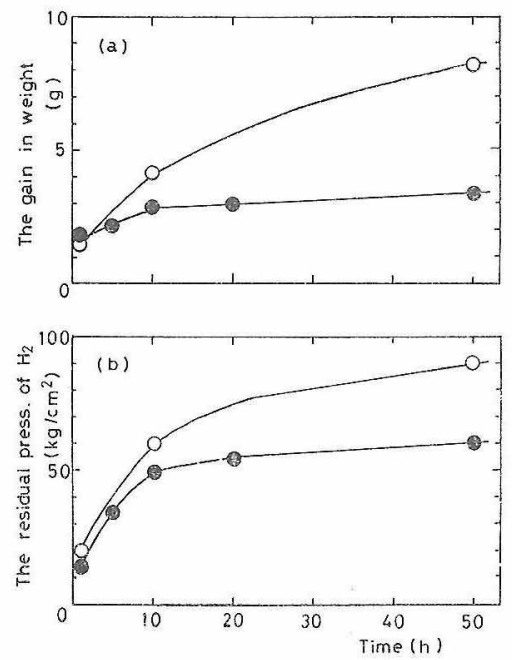

Fig. 6. Changes of (a) the gain in weight of the oxidation products and (b) the residual pressure of $\mathrm{H}_{2}$, produced by dehydration with $\mathrm{Fe}$ powder $(15 \mathrm{~g})$.

: At $420^{\circ} \mathrm{C}, 30 \%$ fill of $0.7 \mathrm{~mol} / \mathrm{kg} \mathrm{NaF}$ solutions.

o : At $450^{\circ} \mathrm{C}, 20 \%$ fill of $1 \mathrm{~mol} / \mathrm{kg} \mathrm{KF}$ solutions.
$\mathrm{Fe}$ は，板状の塊孝用いた場合， $450^{\circ} \mathrm{C}$ において 10 日 間反応した後も, 表面以外はほとど酸化されなかった。 粉末状でけ， $400^{\circ} \mathrm{C}$ では全く反応しなかったが， $420^{\circ} \mathrm{C}$ 以上において酸化が始まり， $\mathrm{Fe}_{3} \mathrm{O}_{4}$ が生成した。そして 図6に示すように，420C では方る程度酸化された後は 反応方進まなかったが， $450^{\circ} \mathrm{C}$ では徐队に進行した。し かし，生成物中に大きなルチル結晶㹥く観察されず， この理由として，Fe では Znあるいは $\mathrm{Al}$ に比べ脱水 速度が遟く，脱我量が少なかったためルチルの析出に六 まり効果がなかったと考えられた。

$\mathrm{Mg}$ は, $200^{\circ} \sim 300^{\circ} \mathrm{C}$ において, すべて $\mathrm{Mg}(\mathrm{OH})_{2}$ ๙ 変化した。したがって，400 $\mathrm{C}$ 以上の反応では脱水反忘 は昇温中に終了してしまうことが想され，契際に $400^{\circ}$ $\sim 450^{\circ} \mathrm{C}$ によいてルチルの䉼出に刘して全く效果はなか った.

$\mathrm{Pb}$ は $327^{\circ} \mathrm{C}$ にて融解し，白金管を腐食するほか， $420^{\circ} \mathrm{C}$ に拉いて水との反応は起きなかった。

以上のように, 種々の金属を脱水剂として用いて実験 を行ったが，ルチルの成辰とともに脱水が進行する金属 は見つけることができなかった。

また，脱水荗に関係なく反応系に作用する脱水の効果 として，発生水素による圧力の增加が考えられるが，表 2 の No. 7，12〜13 の比較から分るように，この程度 の圧力ではその影響はほとんどないと考えられる。

\section{2 .3 脱水の勃㗨について}

脱水剤として $\mathrm{Zn}, \mathrm{Al}$ を用いた場合に比較的大きなル チル結晶が生成した理由として，これらの脱水反応が反 応温度 $420^{\circ} \mathrm{C}$ 付近にて開始され，しか子その速度が比慗 的速く，一時に加なりの量が脱水されたことが考えられ る.したがって，これらの脱水反応は， $\mathrm{TiO}_{2}$ の結晶化 の初期，すなおちルチルの核生成時に作用したと推定さ れる. そこで，これについて詳細に検討するため，Zn 粉末を用いて脱水を行い，生成結晶の時閒による変化及



Fig. 7. The SEM photographs showing crystallization process of $\mathrm{TiO}_{2}$ at $420^{\circ} \mathrm{C}$.

a : R>A, for $5 \mathrm{~h}$ by the ordinary hydrothermal method.

$\mathrm{b}: \mathrm{R}$, for $20 \mathrm{~h}$ by the ordinary hydrothermal method.

$c: R$, for $5 \mathrm{~h}$ by the hydrothermal dehydration method with $\mathrm{Zn}$. d : $\mathrm{R}$, for $20 \mathrm{~h}$ by the hydrothermal dehydration method with $\mathrm{Zn}$. 
びルチル核の添加効果を走䍒型電子顕徽鏡により钼察し t.

図 7 に $0.7 \mathrm{~mol} / \mathrm{kg} \mathrm{NaF}$ 溶液 $40 \mathrm{cc}$, 水酸化チタン $0.5 \mathrm{~g}, \mathrm{Zn} 15 \mathrm{~g}$ を装てんして，420 C に敊いて反応を行 った時の生成結晶の SEM 写真を示寸。この場合，脱水 反応を行った時の生成結晶の SEM 写真を示す。この場 合，脱水反応は 5 時閒で完了しており，脱水量は約 $3 \mathrm{cc}$ であった。压力变化による脱水反忘の進行を図 8 に示 す。 5 時䦎の反応に执いては，通常の水熱法ではルチル の外にアナターゼが約 $40 \%$ 生成し，はっきりした結晶 は観察されなか力たが，脱水法では 100\% ルチルが析

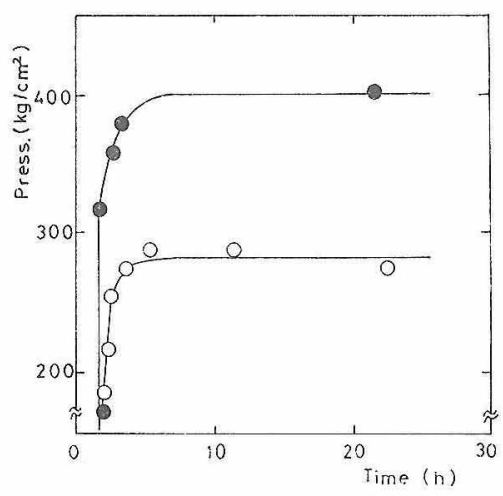

Fig. 8. Pressure increase with reaction time at $420^{\circ} \mathrm{C}$, $30 \%$ fill of $0.7 \mathrm{~mol} / \mathrm{kg}$ NaF solutions under hydrothermal dehydration process.

- With $\mathrm{Zn}$ powder (15 g).

0 : Without dehydration agent.
出し，微結晶の析出が観察された。 そして，20時間の 反応で水熱成莀の結果, 図 $7 \mathrm{~b}, \mathrm{~d}^{\prime}$ のよう結晶の大きさ に差が現れた。

またこれら SEM 写真の比較から，生成絬晶の形状 はアナターゼが存在する場合は原料の水酸化チタンと同 様な非常に細かい粉末が残存して呫り，一方ルチルが生 成した場合は個々の結晶ははっきりした形を有してお り，これは Matthews の報告の゙全く一致し，本实験に 寺いてもアナターゼは原料に用いた水酸化チタンがその まま変化して生成し，ルチルは溶解析出過程を通って生 成するこしが確認された。そして，通常の水熱法ではア ナターゼが吕なり残存することから，ルチルのの結晶化 にはかなりの誘導期間が存在すると考えられる。一方， 脱水法では反応初期に脱水により過飽和となった $\mathrm{TiO}_{2}$ がルチルとして析出しここれを稯としてその後急速に成 長し，ルチル相のみになったと考えられる。したがっ て，この場合の脱水の效果沬析出結晶の核生成の促進に 㗢いたと考えられ，種結晶の添加效果に類似した效果で あると考えられる。

そこで，次に原料中に初奻らルチル粉末を $0.05 \mathrm{~g}$ 添加し， $\mathrm{NaF}$ 溶液 $30 \mathrm{cc}$, 水酸化チタン $0.5 \mathrm{~g}, \mathrm{Zn} \mathrm{15}$ $20 \mathrm{~g}$ 老てんして反岕行った。この奏験では Zn によ る脱水区店を長時閒続けることを期待して，脱水用と試 料の位置を逆にし，その閒に小さな究のあいたステンレ ス棒を装てんし，Zn の位置の温度を低くするすること を試タた。それにより，上部と下部の温度差は $\mathrm{Pb}$ の融 点を利用して測定した結果，約 $20^{\circ} \mathrm{C}$ であり，幾分か脱

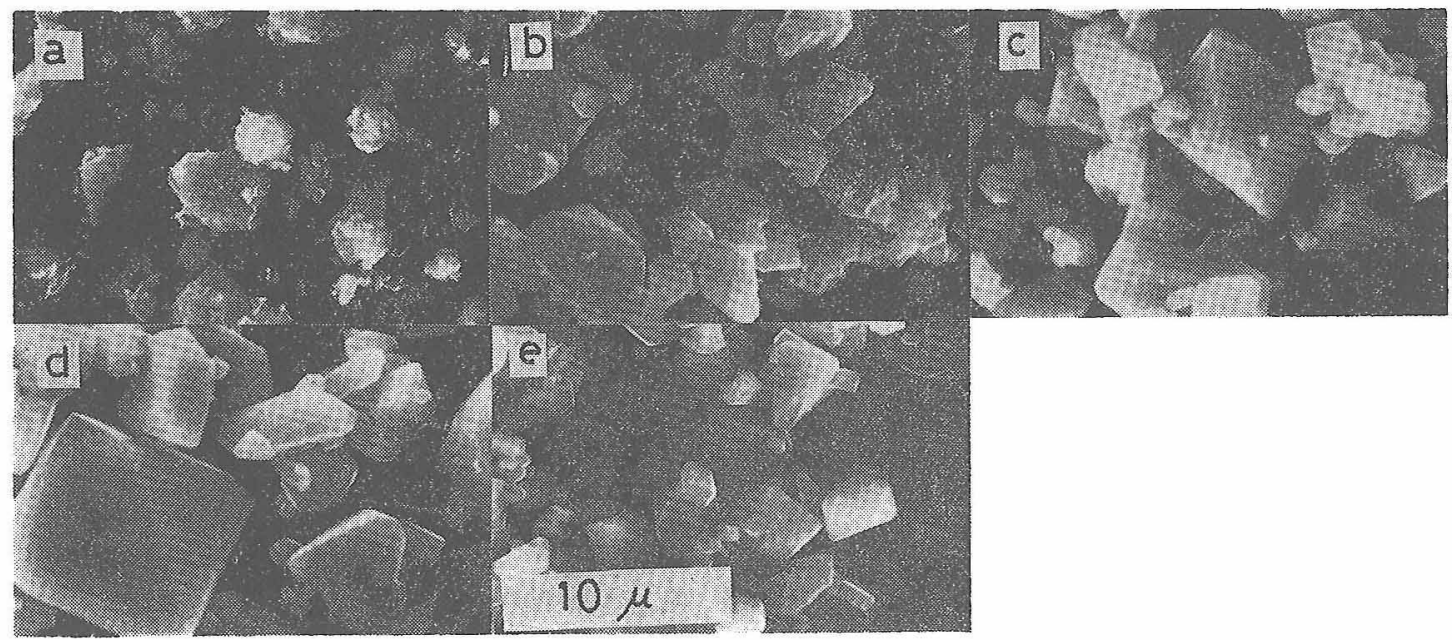

Fig. 9. The SEM photographs showing the progress of crystal growth by dehydration on addition of rutile powder.

a : R>A, for 1 day by the ordinary hydrothermal method.

$\mathrm{b}: \mathrm{R}$, for 5 days by the ordinary hydrothermal method.

c : $\mathrm{R}$, for 1 day by the hydrothermal dehydration method with $\mathrm{Zn}$.

$\mathrm{d}: \mathrm{R}$, for 5 days by the hydrothermal dehydration method with $\mathrm{Zn}$.

e : $\mathrm{R}$, from only amorphous titanium dioxide, for 4 days by the hydrothermal dehydration method with ${ }^{-} \mathrm{Zn}$. 
水速度を遅くすることができたと考えられる。しかし， $420^{\circ} \mathrm{C}$ における 1 日の反応の後 $\mathrm{Zn}$ は完全に酸化されて おり，それ以後は通常の水熱成長であったと考えられ る.

この実験の結果, 図 9 に示すように, 脱水の影響は顕 著に現れた。すなわち，通常の水熱法ではルチルの成長 に時間を要し，1日の反応ではまだアナターゼが $25 \%$ 残存し，はっきりした結晶は観察されず，5日間の反応 の後, 図 9-b のような大きさへ成長したが, 一方脱水 を行った場合, 添加されたルチル粉末は 1 日の反応で図 9-c のように成長した. しかし，5日間の反応でも，脱 水が 1 日以内に終了したため，図 9-d のようにそれ以 上あまり大きく成長はしなかった。 また図 9-e に示すよ らに，ルチルを添加しなかった場合は小さなルチル結晶 しか得られず，この理由としては，脱水が核生成に費さ れ，成長への効果が少なくなるためと考えられる．以上 の結果から，ルチルの核が既に存在する場合は，上述し たような核生成に働く脱水の必要はなく，それは種結晶 上への析出に働くため，より速く結晶が成長したと考え られる.

\section{4. 総括}

水熱下の融剤蒸発法とでもいうべき水熱脱水法により 水酸化チタンからのルチルの結晶化を検討した。

鉱化剂としては， $\mathrm{KF}, \mathrm{CsF}, \mathrm{NaF}$ を用いたが，低温に おけるルチルの生成に対しては，水酸化チタンの溶解析 出が速やかに進行すると考えられる $\mathrm{NaF}$ が適している
ことが示された。

また， $420^{\circ} \mathrm{C}$ において種々の金属を脱水剤として用い た結果，Zn，Al などにより脱水を行った場合に，通常 の水熱法と比べ大きなルチル結晶が析出した。この場 合，脱水反応は結晶化の初期に行われ，主にルチルの核 生成に働いたと考えられる。

更に，結晶核としてルチル粉末を添加した場合， Zn による脱水反応により，その成長が観察され，したがっ て適当な脱水反応を行うことができれば，水熱下におけ る新しい結晶成長法として，この水熱脱水法は期待でき ると考えられる。

\section{文献}

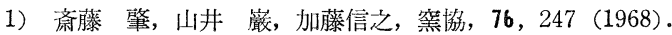

2) T. Oota, H. Saito and I. Yamai, J. Cryst. Growth, 46, 331 (1979).

3) E.F. Osborn, J. Am. Ceram. Soc., 36, 147 (1953).

4) F. Dachille, P.Y. Simons and R. Roy, Am. Mineral., 53, 1929 (1968).

5) Chem. Ab., 66, 32495 (1967).

6) A. Matthews, Am. Mineral., 61, 419 (1976).

7) V.A. Kuznetsov, J. Cryst. Growth, 3/4, 405 (1968).

8) M. Passaret, Y. Toudic, A. Regreny, R. Aumont and J.F. Bayon, ibid., 13/14, 524 (1972).

9）舟木好右衛門，佐伯雄造，工化，59，1291 (1956).

10) R.A. Spurr, Anal. Chem., 29, 760 (1957).

11) F. Izumi and Y. Fujiki, Bull. Chem. Soc. Jpn., 49, 709 (1976).

12) F. Izumi, ibid., 51, 1771 (1978).

13）泉 富士夫, 現代化学, 93，22 (1978).

14）小野修一郎, 山口悟郎, 柳田博明, 清水紀夫, 窐協, 76, 207 (1968). 